\title{
8 \\ Change and the Picnic River
}

By 1970 the Georges River could no longer be seen as a picnic river. The rapid postwar rise in population of the area, the increasing number of factories along its banks and the multiplying rubbish tips dumped on its swamps had led to metropolitan and local headlines like 'River Ruined by Pollution' in 1962, 'Georges River Poisoned' in 1963 and 'Georges River Could Become Sewage Waterway' in 1973. ${ }^{1}$ The main source of contamination was human and garbage waste, but residents feared industrial contamination in the waterways. There certainly was discharge from factories: Bankstown's chief health inspector H. C. Hunt had pointed in 1969 to the high lead levels being discharged into Salt Pan Creek from the battery factory in its upstream reaches. ${ }^{2}$ Hunt had warned too that the damage being caused by the 'garbage explosion' was leading to more and more land being turned into council dumps, scarring the landscape and leaching into the river. ${ }^{3}$ Overall, however, as Kevin Howard, the Bankstown Council health inspector pointed out in March 1973, it was not industrial chemicals that were causing the problems but rather bacterial pollution from human and organic rubbish waste that was so damaging to the Georges River water and, consequently, to the

1 Daily Mirror, 13 September 1962, 7; Propeller, 26 September 1963, 1; Bankstown Torch, 3 January $1973,1$.

2 Commonwealth of Australia, Senate Select Committee on Water Pollution, Minutes of Evidence, vol. 20, 4631, 4664.

3 Hunt, Garbage Disposal, 5. 
land on which it was dumped. ${ }^{4}$ New South Wales Fisheries biologist W. B. Malcolm promised in 1969 that there would be thorough pollution testing of the Georges and Cooks rivers and Botany Bay. Malcolm's grim warning about the lessons from the Cooks River were not lost on Georges River residents when his words were reported in the Bankstown Torch:

\begin{abstract}
Mangrove swamps, river mud flats and sea grasses were essential to nurture young fish. Deepening of rivers through dredging and reclamation of swamps was therefore depriving fish of feeding grounds ... Many swamplands and river flats had been taken over as garbage dumps and playing fields, and waterfront home owners had encroached onto the shallow areas with river pools and jetties. Cooks River was a perfect example of an estuary completely despoiled with playing fields in places where swamps and river flats used to be. ${ }^{5}$
\end{abstract}

Many mangrove and saltmarsh areas had already been 'reclaimed' on the Georges River by 1965, with playing fields planned or already built over the dumped mud and garbage, so a sense of the vulnerability of the remaining low-lying areas must have been widespread among the Georges River estuary communities.

Earlier chapters have traced the first tensions in the 1960s under the impact of postwar pressure. The Picnic Point Regatta Association (PPRA) campaign for the Georges River National Park (mid-1950s to 1961) had tried, and largely failed, to save people's access to river bushland from privatised new home blocks. Then, downstream, the very types of riverbank subdivisions feared by the East Hills campaigners had led to the conflicts after 1962 between the Georges River Oyster Lease Protest Association (GROLPA) - the 'exclusive' waterfront landowners from Como to Sylvania - and the oyster farmers, who were long-established members of the riverside communities round Oatley. The escalating pace of reclamation plans - dumping dredged river mud and rubbish on swamps and mangroves to build playing fields - was spreading alarm along the river.

4 Interchange between CSIRO scientist, G. A. Major, who reassured readers that trace metal content was not a problem in oysters, which he said 'gave a good indication' of the content in river water, and Kevin Howard, Bankstown Council health inspector, who pointed out that the 'real threat' to oysters and the river was bacterial pollution. 'No River Pollution if Proper Care Taken', St George and Sutherland Shire Leader (hereafter Leader), 21 February 1973, 7; 'Oysters' Future "Not So Bright"', Leader, 14 March 1973, 29.

5 'River Test for Pollution', Bankstown Torch, 20 August 1969, 3, reporting on Malcolm's talk to the Cooks River Valley Association. 


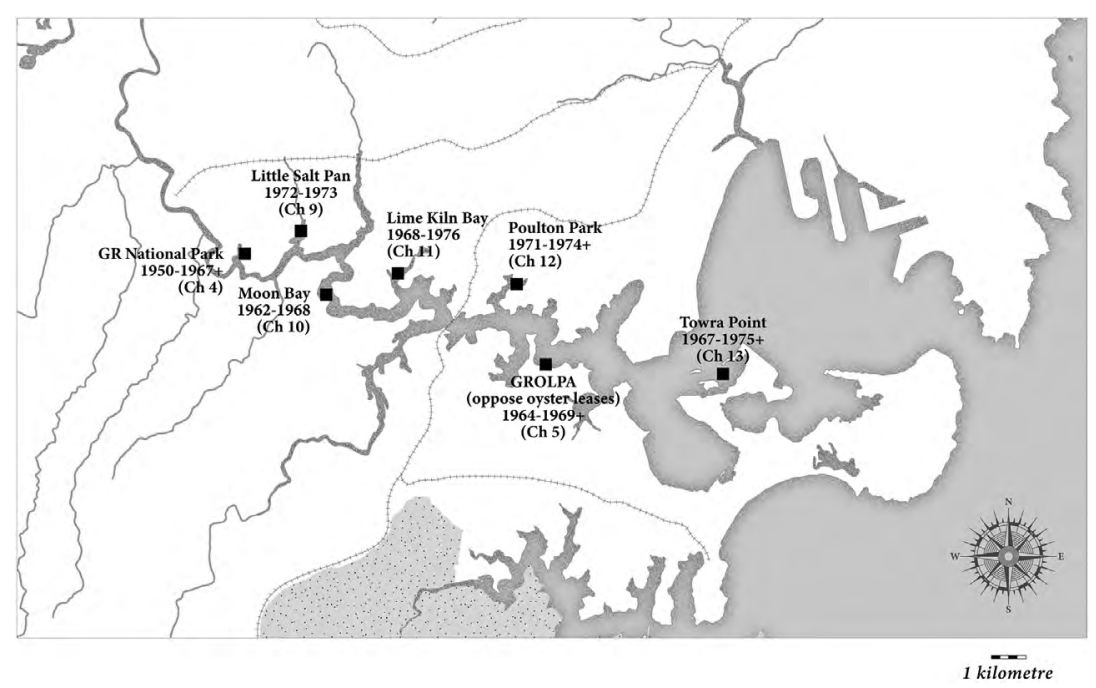

Map 8.1: Locations of the five resident environmental campaigns discussed in the following chapters.

Cartography: Sharon Harrup.

The following chapters consider the five local resident environmental campaigns that flared up on the lower estuary from the mid-1960s to the mid-1970s.

Each of the following chapters will discuss one dispute in detail and the chapters proceed roughly downstream - from Little Salt Pan Creek to Great Moon Bay, Lime Kiln Bay and Oatley Bay and on to Towra Point at the entrance of the Georges River into Botany Bay. Two of these campaigns focused initially on dredging and fishing: those about Great Moon Bay and the airport extensions to Towra Point. The remaining three, Little Salt Pan Creek, Lime Kiln Bay and Poulton Creek at Oatley Bay, were focused largely on the destruction of low-lying land caused by 'reclamation'. Although their emphases varied, each of the campaigns opposed both dredging and the dumping of mud and rubbish onto swamps, mangroves and saltmarsh.

These campaigns are considered separately in the following chapters because each highlights a distinctive strategy or concern. Yet, in fact, all these disputes were occurring at roughly the same time (mid-1960s to mid-1970s) and only a short distance away from each other. They shared 
information and observed each other's tactics and victories, as well as defeats. The reasons behind their distinctive emphases will be considered in the concluding section.

As distinctive as each campaign was, and, indeed, as the whole Georges River in itself was, there were developments in the wider national and international scene that shaped the ways these campaigns were conducted and how successful each was able to be.

Interest in remote areas had been high in the interwar period, with the Sydney Bush Walkers Club a noted example. Led by Myles Dunphy, Marie Byles and others, this group had nurtured plans for a Greater Blue Mountains National Park. ${ }^{6}$ Dunphy (who had moved from Melbourne to Oatley on the Georges River) and others had felt they had succeeded in gaining protection for many of the areas they walked through by interacting with establishment figures and government bureaucracies. ${ }^{7}$

However, these interwar gains had come under threat with postwar changes in technology and economy. Mining for sand threatened coastal areas like Myall Lakes and then oil mining threatened the Great Barrier Reef. Aggressive development and the expansion of farming threatened inland areas like the Little Desert, and the demands of newly electrified homes and industries threatened and eventually destroyed Lake Pedder. ${ }^{8}$ New organisations had developed in response, such as the Nature Conservation Council (NCC) in 1955, but its strategies continued to take the same approaches as the Sydney Bush Walkers: that of negotiating unobtrusively with governments. These threatened places were, in general, remote from cities and were seen as embodying iconic and often pristine examples of Australian natural environments. None of the campaigns aimed to protect damaged and compromised environments - and this was certainly what the Georges River had become! Consequently, the campaigns considered in the following chapters against dredging and reclamations on the Georges

6 Mulligan and Hill, Ecological Pioneers; McLeod, The Summit of Her Ambition.

7 Mulligan and Hill, Ecological Pioneers, 138-53; Hutton and Connors, A History of the Australian Environment Movement, 114-18.

8 Hutton and Connors, A History of the Australian Environment Movement, 92-124. 
River did not initially gain the support of the established environmental organisations like the NCC or its successors, including the Australian Conservation Foundation.

Yet, the desire to protect - and conserve - the unique and the pristine was also felt on the Georges River, and was most clearly expressed by the Oatley Flora and Fauna Society (OFF), also founded in 1955, on the lower estuary. ${ }^{9}$ This society was not involved in either of the resident environmental organisations considered earlier - neither the upstream and working-class PPRA (or the Georges River National Park Trust) in the 1950s and 1960s nor GROLPA, the Como and Sylvania waterfront landowners fighting the oyster farmers during the 1960s. Members of OFF concentrated on educating themselves about issues of conservation on the lower estuary with invited speakers and study visits to scenic and informative conserved landscapes. Some members took more active roles, writing to politicians or to the press, but many were most involved in this self-education process.

At the same time, however, as postwar changes were increasingly threatening iconic landscapes, the decade of the 1960s was one of dramatic national and international social and political change. Rising opposition to the Vietnam War dominated this decade with growing protests against the American intervention in Vietnam and Australia's role in sending conscripts to fight there. This was especially relevant to the Georges River suburban campaigns because it affected many young Georges River men - and their friends and families - in this area where so many children had been settled and grown up since the population increases of the 1950s. Historians of the political campaigns of the late 1960s have often focused on university students (in that period, still necessarily middle class) and the inner-city areas of Sydney or Melbourne. ${ }^{10}$ Yet suburbs like Bankstown had far more young men of conscription age than the inner cities. And the Georges River continued to play host to military spaces like Holsworthy to which conscripts were taken.

9 Fairley, Being Green.

10 See Murphy, Harvest of Fear; King, Australia's Vietnam. In the late 1960s and early 1970s, no Australian government offered financial support for university enrolment. Only after the federal Labor government came to power in 1972 was tertiary education made financially possible for working-class families. 


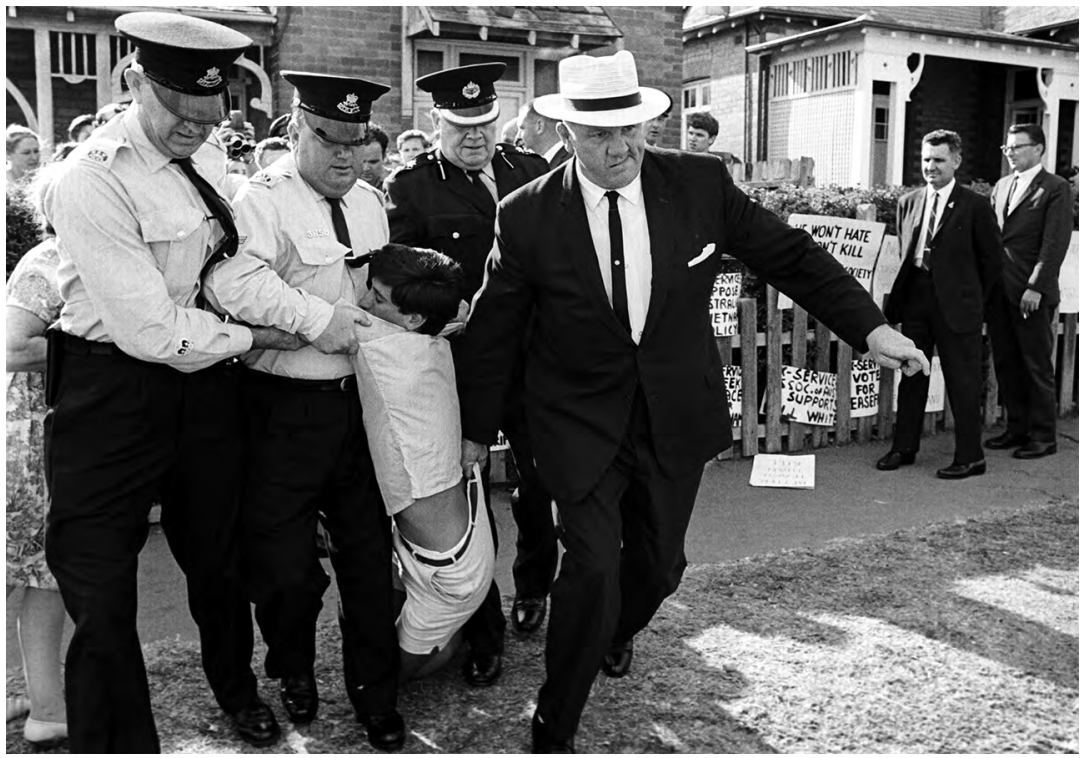

Figure 8.1: Bill White, Vietnam War conscientious objector.

Bill White, a primary school teacher, refused to comply with notices to report for national service because, first, he refused to kill another human being, and, second, because he objected to the US war in Vietnam. This photograph, originally published in the Sun Herald, shows him being dragged from his Gladesville home in late 1966 by police. The photograph was included in K. J. Mason's text for Year 10 history, Experience of Nationhood. Courtesy of Nine Publishing.

Unsurprisingly, then, these 'suburban' areas also had activist movements and protests around the Vietnam War. Bill White, the first conscientious objector against the Vietnam War, was a primary school teacher living in Gladesville, an older area closer to the city, but just as suburban as Bankstown. In July 1966 he refused to cooperate with conscription for Vietnam and was dragged from his home by burly policemen, the scene photographed and published widely in the Sydney press. ${ }^{11}$ The Reverend Ron Page from the Methodist Church in Bankstown was an outspoken critic of Australia's role in the Vietnam War and preached regularly through the later 1960s from his Bankstown pulpit against the conscription

11 'Objector Asked by Army to Consider Position', Sydney Morning Herald, 22 November 1966, 5; 'William White New Charges', Sydney Morning Herald, 28 November 1966, 1; 'Out of Army, White Sets His Wedding Day', Sydney Morning Herald, 24 December 1966, 1; 'Young Teacher's Anti-War Stand Wins Wide Support', Tribune, 27 July 1966, 1; 'Persecuting a Brave Man', Tribune, 10 August 1966, 2; King, Australia's Vietnam, 110; Mason, Experience of Nationhood; ABC Education, 'Fighting Conscription', 6 May 1990, accessed 15 January 2021, education.abc.net.au/home\#!/media/1245268/ fighting-conscription-1966. 
of young men to fight there. ${ }^{12}$ Environmental issues were raised in relation to the weapons used to prosecute the war, not only the defoliants dropped across farming lands but also the new weapons of warfare like napalm and the massive amounts of unexploded ordinances that remained to make farming dangerous for years after. Many small church fellowship groups, such as the St John's Anglican Fellowship I attended at Padstow, took up Page's questions and offered gathering places where young people could discuss the controversies of the war and conscription as well as environmental issues - often without the knowledge or consent of older congregants and ministers. ${ }^{13}$

Concern about the war was widespread among young people around Liverpool at the time, and was discussed widely among students at Liverpool Girls High, who supported their teachers when they struck on 8 May 1970 in the first Sydney Moratorium against the war. ${ }^{14}$ At least some young people growing up in the area went on to university or teachers' college, despite the continuing economic difficulties faced by working-class families in funding tertiary education. Once there, they contributed to the anti-war activism on the early 1970 s. ${ }^{15}$ In one widely publicised example, on 14 February 1972, the draft resister Robert Wood was ordered to report for his national service medical examination at Bankstown District Hospital. He arrived accompanied by nine fellow members of the newly formed Draft Resisters Union, carrying a stuffed dummy of a soldier with a sign around its neck reading: 'I won't go'. Twenty-five other young local men, who all shared the same randomly selected birthday as Wood, had also been ordered to report to the hospital that day. One of them completed his medical but refused to be drafted. Bob Wood burnt his medical notice in front of the group of young men and the surrounding medical staff. The police were called, and Wood and his companions were thrown out and the hospital doors were locked. Although not arrested then, Wood was jailed later in the year for refusing to comply with the draft. ${ }^{16}$ As will be seen in the following chapters, opposition to the war in Vietnam had a very direct impact on one of the campaigns against 'reclamation' along the river.

12 'Provocative Discussion', Bankstown Torch, 9 July 1969, 1.

13 Ray Jarrett, pers. comm.; my own personal observation, Padstow, 1960-70.

14 Dr Meredith Burgmann, a teacher at Liverpool in 1970, pers. comm., 1 Nov 2020.

15 From my own experience and that of others interviewed, Robert Haworth from Peakhurst.

16 'Mucking Up the Medicals', Tribune, 22 Feb 1972, 11; 'Robert Wood: A Man Committed to Peace', Canberra Times, 12 November 1987, 19; Mansell, 'Taking to the Streets'. 
As suggested by Ron Page's work, as well as by the often-whispered conversations about Vietnam that I remember in the Padstow Anglican Fellowship, churches along the Georges River were subject to the wider tensions in social debates at this time, despite continuing to have a role as community gathering places. Some churches played valuable roles in circulating information about the environmental campaigns in this area, but others expressed opposition, alienating long-time parishioners.

Further platforms for agitation around environments were the progress associations. These were secular bodies, but their records were just as diverse and tension ridden as the churches. Progress associations could offer a basis for local racism, as when the PPRA complained about 'unsightly' Aboriginal settlements as well as other 'unauthorised' dwellings on Salt Pan Creek in the 1930s. At times they could call for reclamations, offering strong support for council action as they did for dumping in the upper reaches of Salt Pan Creek in 1941 and 1943. But because they reflected collective, secular expressions of local interests, at times they also demanded action on water quality, as the Padstow Progress Association did when it campaigned against river pollution in $1953 .{ }^{17}$

These progress associations reflected the political orientations of the population. Although the lower Georges River communities were gentrifying in areas like Como and Sylvania, they still - in general contained significant numbers of working people and unionists. Areas like Peakhurst and Lime Kiln Bay were close to the old factories around Mortdale as well as the newly located ones on the upstream reaches and were also close to the railway workshops at Chullora. Many people remained in these areas who were active members of the Communist Party of Australia (CPA), like Mick Staples, a printer who lived at Lime Kiln Bay and had continued to be an activist even after he left his printing job to take up work at Fisher Library. He published his fictionalised life story, Paddo, in $1964 .{ }^{18}$ Some people with a CPA background, like Frank Walker, discussed earlier, had moved to an Australian Labor Party affiliation, while there were others whose sympathies lay on the Liberal side of state politics. All of these networks, across left and right, were

17 Molloy, A History of Padstow, 243-44, citing Padstow Progress Association requests to Bankstown Municipal Council; Rosen, Bankstown: A Sense of Identity, 117, 148, citing Padstow Progress Association protests about pollution in Salt Pan Creek, 1953.

18 Staples, Paddo. 
accessible to local residents through the progress associations, and each of the activists and parliamentarians introduced here and in earlier chapters will reappear as the local conflicts are traced in detail.

The rising pressures on iconic landscapes forced the elderly Myles Dunphy to take up the fight again to save the Colong Caves from mining. At the age of 78, he gave lengthy evidence to the federal Senate Select Committee on Water Pollution in August 1969 as he tried to defend the idea of the pristine Blue Mountains National Park. ${ }^{19}$

But there was a very different style of environmental defence emerging involving direct and often innovative confrontations with major corporations seen to be damaging the environment. The most dramatic example was the first green ban, arising from an unlikely alliance in 1971 between middle-class Hunters Hill matrons and the New South Wales Builders Labourers' Federation (BLF). The Hunters Hill group, calling themselves the Battlers of Kelly's Bush, were trying to stop building developer A. V. Jennings, which had the support of local government, from clearing 4.9 hectares of land (Kelly's Bush) to build 24 'luxury houses'. The battlers called on the BLF for support in mid-1971, and the union responded by refusing to work on the development project. They had used this tactic in their union work before, usually to protect their members' safety or conditions, but increasingly they had been called on to support inner-city residents as they attempted to stop the demolition of their longstanding homes as the city's building boom accelerated. The BLF had previously followed union practice by calling this denial of work on particular sites a 'black ban', but their deepening affiliation with the Aboriginal movement led them to invent a new term due to the implied racism in the term 'black ban'. So, the Kelly's Bush campaign became the world's first 'green ban'. ${ }^{20}$

19 Commonwealth of Australia, Senate Select Committee on Water Pollution, Minutes of Evidence, vol. 19, 4503-38.

20 Burgmann and Burgmann, Green Bans, Red Union, 8-9. 


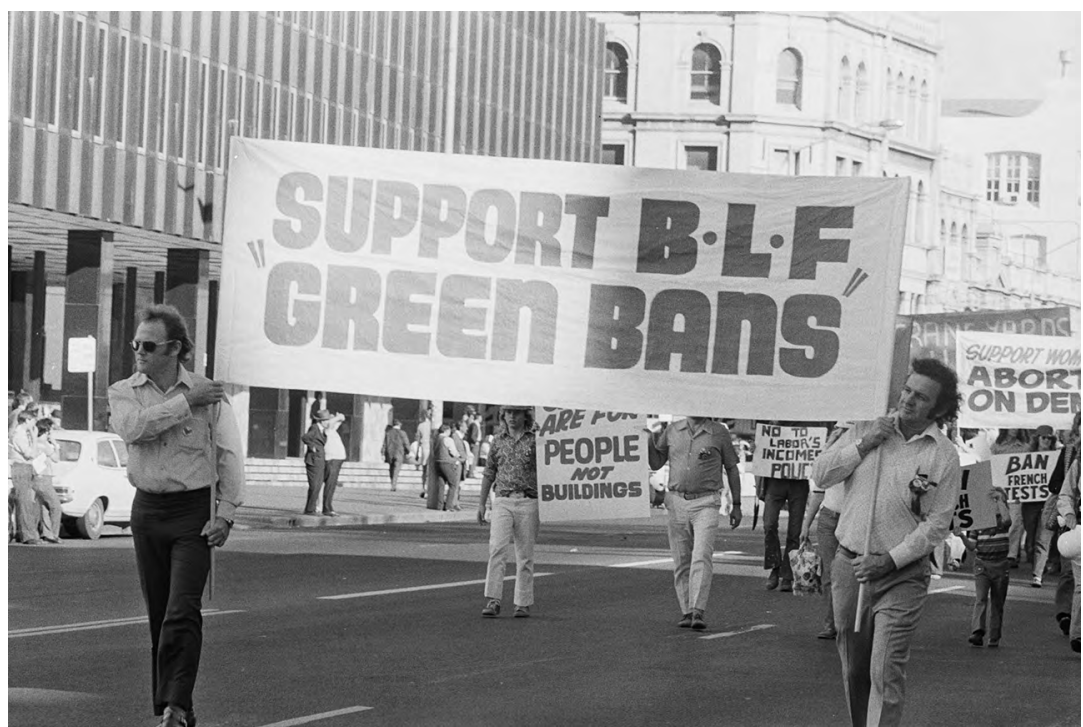

Figure 8.2: Green bans banner, carried by Builders Labourers' Federation activists, Bob Pringle (left) and Jack Mundey (right) in the 1973 May Day March.

The placard just behind is also carried by BLF members and reads: 'Parks are for People, Not Buildings'. Courtesy of Search Foundation, Creative Commons.

The green bans and related resident action of the early 1970 s were notable because of the diversity of social and class interests. Alliances forged by the BLF with university students and other 'trendies' from 'enlightened middle-class' groups were aimed at stopping the 'power of the developers' dollar'. Jack Mundey, well-known communist and BLF spokesperson, argued that Kelly's Bush brought together people he called 'Upper Middle-Class Morning Tea Matrons' with those he identified as 'the other end of the social ladder'. Many BLF campaigns defended working-class and Aboriginal housing, and some actions that began as interventions in demolitions diversified into social issues, such as 'low cost social housing, tenants' rights, public transport and prison issues' ${ }^{21}$ Although the Kelly's Bush dispute did defend a remnant of endemic vegetation, most green bans were mounted to defend the built environment by intervening in urban planning and blunting the 'power of the developers' dollar'.

21 Ibid., 56-58, citing interviews with Jack Mundey, Joe Owens, Kevin Cook and others along with analyses by Mundey (1973), Wendy Bacon (1974) and Andrew Jakubowicz (1984). 
Much of the rising attention in the early 1970s on urban issues focused on big battles with developers and transnational corporations in defence of vulnerable or low-income groups. This came to include the living environment, as the Kelly's Bush green ban demonstrated; however, the battles became more directly related to environmental disturbance with the founding in 1972 of the Total Environment Centre (TEC) by Milo Dunphy, elder son of Myles Dunphy, with Bob Walshe, a teacher from the Sutherland Shire, and others. The TEC rapidly became involved in highly publicised environmental justice conflicts involving major industrial polluters like the oil refineries in Botany Bay. ${ }^{22}$ Although Milo Dunphy had grown up on the Georges River, and retained close friendships in the area, the TEC did not take an active role in any of the Georges River disputes. It did, however, become involved with the Cooks River after a major fish kill when the Sunbeam Corporation Plating factory at Campsie allowed potassium cyanide to be released into the river. ${ }^{23}$ Jeff Nichols, through TEC, investigated environmental conditions on the river and his 1976 report focused on the importance of conserving river environments for informal recreation - like picnics - exactly as the residents had stressed in the Georges River National Park campaign. ${ }^{24}$ In general, however, the TEC concentrated on challenging major corporations and big businesses that were damaging the environment.

There had been some state government attention to the growing popular disquiet about urban environmental amenity. Robert Askin had made promises to GROLPA (which he failed to honour) in the campaign for the 1965 election, and his subsequent government had enacted a number of laws in 1970 aimed at establishing standards for noise and pollution control and for waste disposal, building on the first steps already taken in 1961 with the Clean Air Act. Yet, as the Bankstown health inspector, H. C. Hunt, explained to the federal Senate Select Committee in 1969, the Clean Waters Bill before the New South Wales Parliament, which set maximum allowable discharge volumes for separate chemicals, was simply unworkable on rivers where industries utilised many different chemicals. The Bill would, Hunt maintained, only create a 'licence to

22 Meredith, Myles and Milo; Gowers, 'Dunphy, Myles Joseph (1891-1985)'; Orlovich, 'Dunphy, Milo Kanangra (1929-1996)'. Dexter Dunphy, the younger son of Myles and Margaret Dunphy, is Emeritus Professor in Business at the University of Technology Sydney and has contributed significantly to literature in business on sustainability.

23 ' 15 Tons of Fish Die in Poisoned Waters', Canberra Times, 29 December 1973, 3; 'Pollution

"To Have Long Term Affect”, Canberra Times, 3 January 1974, 7; Tyrrell, River Dreams, 171-74.

24 Tyrrell, River Dreams, 188-93; Nicholls, Cooks River Environmental Survey. 
pollute'. Nevertheless, based on its new legislation, the state proceeded to set up the State Pollution Control Commission, although it had no regulatory power until mid-1974. This was the body to which the residents campaigning for Georges River environments would appeal for support in the coming years.

Disputes multiplied in the early 1970s, with the Kelly's Bush campaign just one of a growing number of residents' groups in the inner city who were threatened by the galloping pace of development in Sydney. In 1971 a network developed between them known as the Coalition of Resident Action Groups (CRAG). Just two years later, in August 1973, it had over 80 groups affiliated to it. CRAG was dominated, however, by inner-city groups who were campaigning to stop demolitions of low-income and working-class housing. Among all members, those that CRAG identified as 'parks and conservation' groups were only a small minority and, according to Tharunka, they felt marginalised and out of place. Even then, this small minority were opposing large corporate developments that threatened long-established inner-urban parks like Centennial Park - itself established in 1888 by 'reclaiming' a swamp. There were, in 1973, no apparent links in CRAG with the south-western suburbs of the city and few calls to conserve native bushland, other than the Kelly's Bush campaign at Hunters Hill. ${ }^{25}$

Conflicts with big corporations and major developers over pollution and demolitions would today be readily recognised as 'environmental', whether the issues are about living environments like Kelly's Bush or built environments like derelict housing at The Rocks or Millers Point. Yet recognition of the issues as environmental, even the language used to identify environmental problems, was not a given but instead emerged over time, shaped by local and international processes. The central concerns of all of the campaigns in the following chapters exemplify this process of change, because they are about places that, in the 1960s and 1970 s, the campaigners called 'mangrove swamps'.

Over these same decades, a new body of ideas was emerging about such places, which became known as 'wetlands', although the language in which they were named took a long time to evolve. The initiating event was the 1971 international intergovernmental agreement known as the Ramsar

25 Roddewig, Green Bans, 22-28; 'CRAG', Tharunka, 2 August 1973, 16, article reviewing CRAG membership and directions. 
Convention on Wetlands of International Importance Especially as Waterfowl Habitat. The convention listed all the places it identified as 'wetlands', including inland marshes and estuarine or coastal swamps. Australia was one of the first signatories of the convention and soon after pursued international diplomacy possibilities by negotiating a treaty with Japan to protect the resting and feeding places needed by migrating birds. Yet the term 'wetlands' was unfamiliar in Australia, as was the Ramsar Convention's focus on birdlife. ${ }^{26}$ Migrating birds were only one way to understand the ecology and behaviour of the places protected by the Ramsar Convention. Such places have many roles in relation to a wide variety of wildlife aquatic, earthbound and avian. The Georges River campaigns traced over the following chapters offer insight into the diverse and changing ways that places later understood as 'wetlands' were identified and valued in the 1960s and 1970s, before that terminology and body of ideas became dominant. At the same time, the changes in language about the places that the Georges River residents were so concerned about suggests one reason these campaigns have not been recognised as part of the emerging environmental movement of the times.

While the spectacular conflicts over green bans or the TEC campaigns against oil refineries in Botany Bay are today readily recognised as 'environmental' or 'environmental justice' campaigns, the problems faced by Georges River campaigners were seldom over private development. They were much more frequently about the actions of local government in the context of waste disposal and recreational land management, as the following chapters discuss. The campaigners consistently argued that it was state and federal governments that should be bearing the financial, technical and policy responsibility, but it was invariably local governments at the frontline of these conflicts. Since the private developers who tended to be involved in inner-city conflicts were absent, the unions on whom the campaigners could call for support were also very different in membership and political affiliation, as the following chapters show.

The Georges River National Park Trust had initially involved both residents and officials from three local government councils: Bankstown and Hurstville on the northern side and Sutherland on the southern side. The interests of councils and local residents often seemed to diverge over

26 This recognition of the historical process of change in popular understanding of 'watery places' and in the language used to represent them is discussed extensively by O'Gorman, Wetlands in a Dry Land. 
the life of the trust, as the local government bodies focused on shoring up votes and employee jobs, rather than on the interests of resident groups like the PPRA. The state government eventually preferred its own employees, like those in its National Parks and Wildlife Service (NPWS) and, as discussed earlier, in 1987 it ended all local resident or council involvement with park management.

Yet, by the late 1960s, even though clumsy, it was local government councils and their staff who were most directly grappling with the impacts of economic, social and environmental change. This was why these local councils became the frontline. In each of the environmental conflicts along the more industrialised and heavily populated northern side of the river, resident groups became pitted against councils who were supposed to be representing them: Bankstown, Hurstville and, on the lower reaches, Kogarah.

There were differences between the councils that showed the continuing effects of earlier conflicts over the national park, as the case of Little Salt Pan Creek demonstrates. Distrust of formal environmental management bodies had lingered after the marginalisation of local representatives on the Georges River National Park Trust and, most of all, after the dismissal by the state government of the Georges River lands as a national park in 1967. So, when the pace of 'reclamations' began to gather from 1968 onwards, there were ready audiences for dissatisfaction with councils and state government agencies like NPWS.

Bankstown appeared to have learnt some lessons from its earlier encounters as well as from the changing views of local residents about 'reclamations'. As we consider in the following chapters, the council at Hurstville along with Kogarah with whom it shared similar concerns and policies - did not draw this lesson at all. These two councils seemed determined to escalate the old strategies of dredging, dumping and 'reclaiming' to make controlled and disciplined spaces. On the southern side, Sutherland Council had jurisdiction over the whole bank of the Georges River estuary, and it retained more local resident support. Unlike Hurstville and Kogarah, it contained some councillors who were sympathetic to the new ecological concerns but, as we shall see, Sutherland also faced very different issues to those on the northern shore. 
This text is taken from Georges River Blues: Swamps, Mangroves and Resident Action, 1945-1980, by Heather Goodall, published 2022, The Australian National University, Canberra, Australia.

doi.org/10.22459/GRB.2021.08 